\title{
Glycerol Oxidation and Triose Reduction by Pyridine Nucleotide-linked Enzymes in the Fission Yeast Schizosaccharomyces pombe
}

\author{
By YUEN-CHONG KONG, JOHN W. MAY AND JOHN H. MARSHALL* \\ Department of Microbiology, Monash University, Clayton, Victoria 3168, Australia
}

(Received 19 November 1984; revised 19 February 1985)

\begin{abstract}
The fission yeast Schizosaccharomyces pombe has been shown to produce four separate pyridine nucleotide-linked glycerol dehydrogenases (or triose reductases), distinguished by differences in their coenzyme specificity $\left(\mathrm{NAD}^{+}\right.$or $\mathrm{NADP}^{+}$) and oxidation product (dihydroxyacetone or glyceraldehyde). Evidence for four separate activities was obtained by heat inactivation studies, comparison of cells grown under different conditions, and separation and partial purification of the enzymes. One enzyme, a glycerol : NAD ${ }^{+} 2$-oxidoreductase is repressed by glucose but not induced by glycerol and appears to function primarily in glycerol catabolism. The second, a glycerol : NADP+ 2-oxidoreductase is stimulated by growth on glucose and appears to function as a dihydroxyacetone reductase involved in glycerol synthesis. The third has the properties of a glycerol: $\mathrm{NADP}^{+}$oxidoreductase, while the fourth is, in fact, alcohol dehydrogenase (alcohol: $\mathrm{NAD}^{+}$oxidoreductase) which possesses weak activity as a glycerol: $\mathrm{NAD}^{+} 1$ oxidoreductase.
\end{abstract}

\section{INTRODUCTION}

The fission yeast Schizosaccharomyces pombe can use glycerol as its sole source of carbon and energy. Until recently it has been generally assumed that all yeasts which utilize glycerol, first convert it to $s n$-glycerol 3-phosphate by glycerol kinase, and then oxidize this product to dihydroxyacetone phosphate by a glycerol-3-phosphate dehydrogenase, as has been shown for several yeasts (Bergmeyer et al., 1961; Gancedo et al., 1968; Sprague \& Cronan, 1977). We have shown that a different mechanism operates in $S$. pombe, which first oxidizes glycerol to dihydroxyacetone (DHA) by an $\mathrm{NAD}^{+}$-linked glycerol dehydrogenase, and then phosphorylates the triose by a specific DHA kinase (May \& Sloan, 1981; May et al., 1982). Our initial studies with two strains of $S$. pombe have now been extended to a further 37 strains, each of which possessed glycerol dehydrogenase but no glycerol kinase (G. Vasiliadis \& J. W. May, unpublished results). This alternative route of glycerol utilization has also been reported to occur in some bacteria (Lin, 1976), and in several yeasts in addition to $S$. pombe (Babel \& Hofmann, 1982). The discovery of this alternative pathway for glycerol utilization in $S$. pombe prompted us to undertake a more detailed study of its glycerol metabolism. We now present evidence for not one, but four, distinct pyridine nucleotide-linked enzymes which can catalyse the oxidation of glycerol and the reduction of one or both of the trioses, DHA and glyceraldehyde (GLD).

\section{METHODS}

Organism. The organism used was $S$. pombe strain $972 \mathrm{~h}^{-}$, maintained as described previously (May \& Sloan, 1981).

Growth of cells and preparation of cell extracts. Methods for growing and harvesting cells and preparing cell extracts have been described (May \& Sloan, 1981; May et al., 1982). Larger batches of cells were prepared by

Abbreviations: DHA, dihydroxyacetone; GLD, DL-glyceraldehyde; ADH, alcohol dehydrogenase; GDH, glycerol dehydrogenase (specific enzymes numbered 1 to 4); $g d h$, glycerol oxidizing activity (specific reactions are numbered $g d h 1$, oxidation at $\mathrm{C}_{1}, \mathrm{NAD}^{+}$-linked; $g d h 2$, oxidation at $\mathrm{C}_{2}, \mathrm{NAD}^{+}$-linked; gdh3, oxidation at $\mathrm{C}_{1}$, $\mathrm{NADP}^{+}$-linked; $g d h 4$, oxidation at $\mathrm{C}_{2}, \mathrm{NADP}^{+}$-linked). 
growth in one or more (up to six) 141 fermentation vessels (Quickfit) containing 121 Edinburgh minimal medium no. 2 (Mitchison, 1970). For some experiments, the carbon and energy source in the medium was modified by replacing the glucose with $1 \%(\mathrm{v} / \mathrm{v})$ glycerol. Each vessel was inoculated with $120 \mathrm{ml}$ starter culture and incubated in a water bath at $30^{\circ} \mathrm{C}$ for $70 \mathrm{~h}$ with aeration ( 1 litre air $\mathrm{min}^{-1}$ ) and stirring ( 220 r.p.m.).

Enzyme assays. Enzyme activities were measured at $20^{\circ} \mathrm{C}$ in cuvettes containing a total volume of either $3.0 \mathrm{ml}$ or $1.0 \mathrm{ml}$. Pyridine nucleotide-linked dehydrogenase activities were measured by determining the initial rates of reduction of $\mathrm{NAD}^{+}$or $\mathrm{NADP}^{+}$, or oxidation of NADH or NADPH, by following changes in $A_{340}$ with a Perkin Elmer, model 552, double-beam recording spectrophotometer. A value of $6.22 \times 10^{-3} \mathrm{lmol}^{-1} \mathrm{~cm}^{-1}$ was used for the molar absorption coefficients of NADH and NADPH at $340 \mathrm{~nm}$. Specific activities are given as nmol substrate used $\min ^{-1}$ (mg protein $)^{-1}$.

Glycerol dehydrogenases. Dehydrogenation of glycerol may occur at either $\mathrm{C}_{1}$ or $\mathrm{C}_{2}$ producing GLD or DHA respectively and it may be linked to either $\mathrm{NAD}^{+}$or $\mathrm{NADP}^{+}$, the reactions possible being:

$$
\begin{aligned}
& \text { (1) Glycerol }+\mathrm{NAD}^{+} \rightleftharpoons \mathrm{GLD}+\mathrm{NADH}+\mathrm{H}^{+}(g d h 1) \\
& \text { (2) Glycerol }+\mathrm{NAD}^{+} \rightleftharpoons \mathrm{DHA}+\mathrm{NADH}+\mathrm{H}^{+}(g d h 2) \\
& \text { (3) Glycerol }+\mathrm{NADP}^{+} \rightleftharpoons \mathrm{GLD}+\mathrm{NADPH}+\mathrm{H}^{+}(g d h 3) \\
& \text { (4) Glycerol }+\mathrm{NADP}^{+} \rightleftharpoons \mathrm{DHA}+\mathrm{NADPH}+\mathrm{H}^{+}(g d h 4)
\end{aligned}
$$

It is not possible to distinguish between (1) and (2) or between (3) and (4) by measuring glycerol oxidation; to do this the reverse reaction, reduction of GLD or DHA, must be measured. Since a proton is involved in these reactions the equilibrium is affected by $\mathrm{pH}$, a high $\mathrm{pH}$ favouring glycerol removal and a low $\mathrm{pH}$ favouring its formation, but glycerol formation is favoured thermodynamically, the equilibrium constants for these reactions being about $10^{-12}$ [e.g. $2.4 \times 10^{-12}$ calculated for reaction (2) by McGregor et al. (1974)]. The activities represented by equations (1) to (4) will be designated $g d h 1, g d h 2, g d h 3$ and $g d h 4$ respectively, while specific enzymes catalysing predominantly one of these activities will be designated GDH1, GDH2, GDH3 or GDH4. Such enzymes may not necessarily display exclusive specificity for one substrate or one coenzyme.

Glycerol oxidation linked to either $\mathrm{NAD}^{+}$or NADP ${ }^{+}$was measured by a modification of the method of Ruch et al. (1974). Oxidation was favoured by buffering the system at $\mathrm{pH} 9.5$ and including hydrazine to trap the product. The reaction mixture contained the enzyme preparation, $0.6 \mathrm{~mm}-\mathrm{NAD}^{+}, 2 \mathrm{~mm}-\left(\mathrm{NH}_{4}\right)_{2} \mathrm{SO}_{4}, 10 \mathrm{~mm}$-glycerol, $60 \mathrm{~mm}$-hydrazine hydrate and $40 \mathrm{~mm}$-glycine/ $\mathrm{KOH}$ buffer $(\mathrm{pH} 9 \cdot 5)$.

Triose reduction linked to $\mathrm{NADH}$, though favoured by low $\mathrm{pH}$, could be measured in crude extracts only at pH 9 or higher because of the presence of an NADH oxidase system, which was very active in less alkaline solutions. It was not possible to circumvent the NADH oxidation at $\mathrm{pH} 6$ by the addition of cyanide since this also inhibited triose reductase activity. The assay system contained the enzyme preparation, $80 \mathrm{mM}-\mathrm{K}_{2} \mathrm{CO}_{3} / \mathrm{KHCO}_{3}$ buffer ( $\mathrm{pH} 9 \cdot 0), 0 \cdot 3 \mathrm{~mm}-\mathrm{NADH}$ and $5 \mathrm{~mm}-\mathrm{DHA}$ or GLD. The system for measuring triose reduction linked to NADPH contained the enzyme preparation, 50 mM-potassium hydrogen phthalate $/ \mathrm{KOH}$ buffer (pH 6.0), 0.3 mMNADPH and 5 mM-DHA or GLD.

Glycerol oxidase. Glycerol oxidase activity was measured by the method of Uwajima et al. (1979) which is based on a colorimetric determination of the $\mathrm{H}_{2} \mathrm{O}_{2}$ formed.

Alcohol dehydrogenase. Alcohol dehydrogenase (ADH) could be measured by the same method as for NAD+linked glycerol oxidation except that glycerol in the assay mixture was replaced by 50 mM-ethanol. It was more commonly measured in the reverse, thermodynamically favoured, direction by a method similar to that used for measuring triose reductase, the assay system containing the enzyme preparation, $80 \mathrm{~mm}$-carbonate buffer (pH 9.0), 0.3 mM-NADH and $5 \mathrm{~mm}$-acetaldehyde.

Protein. The protein content of crude extracts and partly purified preparations was measured by the biuret method (Koch \& Putnam, 1971). For solutions which contained little or no UV-absorbing material other than protein, the protein content was assayed spectrophotometrically by measuring $A_{214}$ (Waddell, 1956). Bovine serum albumin was the reference protein for each method.

Electrophoresis. Enzyme preparations were monitored by disc gel electrophoresis following the general method of Davis (1964) using an anionic system at $\mathrm{pH} 8.3$ and $7.5 \%(\mathrm{w} / \mathrm{v})$ polyacrylamide gel. After electrophoresis, the gels were stained either for protein with Coomassie brilliant blue $\mathbf{R}$, or for enzyme activity with a mixture containing $100 \mathrm{~mm}$-carbonate buffer $(\mathrm{pH} 9.0), \quad 0.15 \mathrm{mM}^{-N_{A D}}{ }^{+}$or $\mathrm{NADP}^{+}$, phenazine methosulphate $\left(0 \cdot 025 \mathrm{mg} \mathrm{ml}^{-1}\right)$, 3-(4,5-dimethylthiazol-2-yl)-2,5-diphenyltetrazolium bromide (MTT, $\left.0.25 \mathrm{mg} \mathrm{ml}^{-1}\right)$ and $50 \mathrm{mM}$ glycerol or ethanol.

Heat treatment of extracts. This was done in a thermostatically controlled circulating water bath maintained at the desired temperature. The extract $(2.0 \mathrm{ml})$ in a glass tube was immersed in the bath and gently stirred with a magnetic stirrer. After $10 \mathrm{~min}$ the tube was rapidly cooled in ice and any precipitate removed by centrifugation.

Enzyme fractionation methods. All steps were done at $0-4{ }^{\circ} \mathrm{C}$.

Step 1. Ethodin treatment. Crude extracts were treated with 6,9-diamino-2-ethoxyacridine lactate (ethodin) to precipitate nucleic acids (Thorner \& Paulus, 1971). A $2 \cdot 5 \%$ (w/v) solution in $20 \mathrm{~mm}-\mathrm{Tris} / \mathrm{HCl}$ (pH 7.6) was added 
dropwise with stirring to the extract (contained in $100 \mathrm{~mm}$-Tris/ $\mathrm{HCl}, \mathrm{pH} 7.6$ ) to a final concentration of $50 \mathrm{mg}$ ethodin to $1 \mathrm{~g}$ protein, and stirred overnight. The heavy yellow precipitate was removed by centrifugation at $27000 \mathrm{~g}$ for $30 \mathrm{~min}$ leaving a clear yellow solution.

Step 2. Ammonium sulphate precipitation. The supernatant solution from step 1 was fractionated by stepwise precipitation with increasing concentrations of $\left(\mathrm{NH}_{4}\right)_{2} \mathrm{SO}_{4}$. Solid $\left(\mathrm{NH}_{4}\right)_{2} \mathrm{SO}_{4}$ was added slowly with stirring to the desired concentration and the solution was stirred gently for $30 \mathrm{~min}$. The precipitate was removed by centrifugation. The process was repeated by adding more solid $\left(\mathrm{NH}_{4}\right)_{2} \mathrm{SO}_{4}$ to the measured volume of supernatant solution, the amount required to give the next higher chosen concentration being determined by reference to Wood's tables (Wood, 1976). The precipitate was again removed by centrifugation. The most useful steps for fractionation were found to be $1.8 \mathrm{M}-, 2.5 \mathrm{M}$ - and $3.8 \mathrm{M}-\left(\mathrm{NH}_{4}\right)_{2} \mathrm{SO}_{4}$. Precipitates were dissolved in a small volume of $100 \mathrm{~mm}$ - Tris $/ \mathrm{HCl}(\mathrm{pH} \mathrm{7.6)}$. Before testing for enzyme activity solutions were desalted and freed from residual ethodin by passage through a column of Sephadex G-25.

Step 3. Ion exchange chromatography. A column of DEAE-cellulose (Whatman DE $52 ; 1.5 \times 20 \mathrm{~cm}$ or other appropriate size) was equilibrated with $20 \mathrm{~mm}-\mathrm{Tris} / \mathrm{HCl}(\mathrm{pH} 8.0)$. The sample was applied to the column, and then eluted with stepwise increasing concentrations of $\mathrm{KCl}(0-1.5 \mathrm{M})$ in the same buffer. The eluate was collected in $2 \cdot 0 \mathrm{ml}$ fractions.

Step 4. Gel permeation chromatography. Fractions from step 3 which had enzyme activity were pooled and concentrated to $1.5 \mathrm{ml}$ by ultrafiltration through a membrane filter in a stirred cell (Cell 8050 , Diaflo membrane PM 30; Amicon). The sample was loaded on to a Sephadex G-200 column $(2.0 \times 75 \mathrm{~cm})$ previously equilibrated with $20 \mathrm{~mm}-\mathrm{Tris} / \mathrm{HCl}(\mathrm{pH} 8.0)$, eluted with the same buffer and collected in $2.0 \mathrm{ml}$ fractions.

Purification of $A D H$. ADH from $S$. pombe was isolated and purified from glucose grown cells harvested in the stationary phase by the rapid purification method of Scopes et al. (1981), in which most of the cell protein is denatured with a high concentration of ethanol; a purification of 110-fold was achieved.

Chemicals. DHA, GLD, 6,9-diamino-2-ethoxyacridine lactate (ethodin) and Tris were from Sigma; NAD ${ }^{+}$ (grade II), NADH (grade II), NADP ${ }^{+}$and NADPH were mainly from Boehringer, with some samples from Sigma; Sephadex gel permeation media were from Pharmacia. Other chemicals were of analytical reagent grade when available and were from BDH or Ajax (Sydney, Australia).

\section{RESULTS}

\section{Types of glycerol dehydrogenases}

All four types of pyridine nucleotide-linked GDH activity were found in S. pombe, i.e. $g d h 1$, $g d h 2, g d h 3$ and $g d h 4$, but we were unable to detect any glycerol oxidase.

\section{Heat stability of enzymes}

A comparison was made of the degree of inactivation of the different enzyme activities in extracts which had been heated for $10 \mathrm{~min}$ at temperatures up to $80^{\circ} \mathrm{C}$. Representative results are shown in Table 1 . The greatest stability was shown by gdhl and ADH, both of which retained activity at $80^{\circ} \mathrm{C}$. The $g d h 3$ activity was the most labile, being partly inactivated at $50{ }^{\circ} \mathrm{C}$ and completely inactivated at $60^{\circ} \mathrm{C}$, while gdh2 and gdh4 showed little loss of activity at $60{ }^{\circ} \mathrm{C}$ but complete inactivation at $70^{\circ} \mathrm{C}$. These results suggest the presence of at least three separate enzymes.

\section{Effect of different growth conditions}

The results obtained in a series of experiments in which a comparison was made of enzyme activities in cells grown on either glucose or glycerol, and harvested either during exponential growth or after the culture had reached the stationary phase are shown in Table 2 . In cultures grown to the stationary phase on glucose, no glucose remained, but in cultures grown to the stationary phase on glycerol, much glycerol still remained. Glucose-stationary cells (B) and glycerol grown cells, whether exponential or stationary $(C)$ did not differ in their enzyme activities. In comparison to cells (B) and (C), glucose-exponential cells (A) showed very strong $(97 \%)$ repression of $g d h 2$ activity, no change in $g d h 1, g d h 3$ or ADH and a small $(17 \%)$ increase in $g d h 4$. The NAD ${ }^{+}$-linked glycerol oxidation rate (which includes both $g d h 1$ and $g d h 2$ ) in cells (A) relative to cells (B) or (C) was consistent with strong repression of $g d h 2$ while the NADP ${ }^{+}$-linked glycerol oxidation rate (which includes both $g d h 3$ and $g d h 4$ ) showed a $200 \%$ increase in contrast to the relatively small increase (in $g d h 4$ only) shown by measurements in the reverse direction. 
Table 1. Heat inactivation of glycerol dehydrogenases in cell extracts

Extracts were held at the specified temperature for $10 \mathrm{~min}$ (see Methods). The values equivalent to $100 \%$ were $31,65,26,110$ and $1500 \mathrm{nmol}$ substrate used $\min ^{-1}$ (mg protein) $)^{-1}$ for $g d h 1, g d h 2, g d h 3$, gdh 4 and $\mathrm{ADH}$ respectively.

\begin{tabular}{|c|c|c|c|c|c|}
\hline \multirow[b]{2}{*}{$\begin{array}{l}\text { Activity } \\
\text { type }\end{array}$} & \multirow[b]{2}{*}{$\begin{array}{c}\text { Assay system } \\
\text { (substrate/coenzyme) }\end{array}$} & \multicolumn{4}{|c|}{$\begin{array}{l}\text { Oxidoreductase activity } \\
\text { remaining (unheated } \\
\text { extract }=100 \text { ) }\end{array}$} \\
\hline & & $50{ }^{\circ} \mathrm{C}$ & $60^{\circ} \mathrm{C}$ & $70^{\circ} \mathrm{C}$ & $80^{\circ} \mathrm{C}$ \\
\hline$g d h 1$ & GLD/NADH & 75 & 60 & 40 & 10 \\
\hline$g d h 2$ & DHA/NADH & 85 & 80 & 0 & 0 \\
\hline$g d h 3$ & GLD/NADPH & 60 & 0 & 0 & 0 \\
\hline$g d h 4$ & DHA/NADPH & 90 & 70 & 0 & 0 \\
\hline ADH & Acetaldehyde/NADH & 100 & 100 & 80 & 40 \\
\hline
\end{tabular}

Table 2. Effect of growth conditions on glycerol dehydrogenases

The oxidoreductase activities were determined in extracts of cells grown on glucose and harvested during the exponential phase (A), of cells grown on glucose and harvested during the stationary phase when glucose was not detectable (B), and of cells grown on glycerol (C). With the latter, specific activities did not change with time of harvesting.

\begin{tabular}{|c|c|c|c|c|c|}
\hline \multirow[b]{2}{*}{$\begin{array}{l}\text { Activity } \\
\text { type }\end{array}$} & \multirow[b]{2}{*}{$\begin{array}{c}\text { Assay system } \\
\text { (substrate/coenzyme) }\end{array}$} & \multicolumn{3}{|c|}{$\begin{array}{c}\text { Oxidoreductase activity } \\
\left.\text { [nmol substrate used } \mathrm{min}^{-1}(\mathrm{mg} \text { protein })^{-1}\right]\end{array}$} & \multirow[b]{2}{*}{$\begin{array}{l}\text { Activity } \\
\text { ratio, } \mathrm{A}: \mathrm{B}\end{array}$} \\
\hline & & A & B & $\mathrm{C}$ & \\
\hline$g d h 1$ & GLD/NADH & 28 & 26 & 24 & $1 \cdot 1$ \\
\hline$g d h 2$ & DHA/NADH & $1 \cdot 5$ & 50 & 50 & 0.03 \\
\hline$g d h 3$ & GLD/NADPH & 17 & 18 & 17 & $1 \cdot 0$ \\
\hline$g d h 4$ & DHA/NADPH & 105 & 90 & 90 & $1 \cdot 2$ \\
\hline$g d h 1+g d h 2$ & Glycerol/NAD ${ }^{+}$ & 3 & 27 & 28 & $0 \cdot 1$ \\
\hline$g d h 3+g d h 4$ & Glycerol/NADP+ ${ }^{+}$ & 15 & 5 & 4 & $3 \cdot 0$ \\
\hline $\mathrm{ADH}$ & Acetaldehyde/NADH & 1600 & 1600 & 1600 & 1.0 \\
\hline
\end{tabular}

These results, which show that $g d h 2$ and $g d h 4$ activities cannot be due to the same enzyme, taken in conjunction with the relative heat stabilities, make it necessary to postulate the presence of four separate GDH enzymes.

\section{Separation of enzyme activities}

Cells containing all four GDH activities were obtained either by growth on glycerol or by growth on glucose to the stationary phase; the latter method gave more rapid growth and a higher cell density. Extracts prepared from such cells were fractionated as described in Methods through step 1 (ethodin treatment) and step 2 (successive precipitation with $1.8 \mathrm{M}, 2.5 \mathrm{M}$ and $\left.3.8 \mathrm{M}-\left(\mathrm{NH}_{4}\right)_{2} \mathrm{SO}_{4}\right)$ to yield three fractions; Table 3 shows the distribution of activities in these fractions: All the gdh2 activity and most of the gdh4 activity were found in fraction I $(1.8 \mathrm{M})$; $g d h 1$ and ADH showed highest activity in fraction II $(2.5 \mathrm{M})$ with much lower activity in fraction I, while $g d h 3$ activity was highest in fraction III ( $3.8 \mathrm{M})$ but with some appearing in fractions I and II. It is important to bear in mind that specific activities of different enzyme reactions cannot be compared directly when the assay conditions differ (e.g. $g d h 2$ and $g d h 4$ ).

Further purification of fraction I was achieved by chromatography on DEAE-cellulose (step 3). Elution with increasing concentrations of $\mathrm{KCl}$ produced a fraction possessing only $g d h 2$ and gdh4 activity. Gel permeation chromatography of this material (step 4) gave pure glycerol : NAD ${ }^{+}$2-oxidoreductase $(\mathrm{GDH} 2)$; details of its purification and characterization are given in the accompanying paper (Marshall et al., 1985), where it is shown that its activity with NADPH ( $g d h 4$ activity) is about $30 \%$ of that with NADH. 
Table 3. Separation of glycerol dehydrogenase activities by precipitation with $\left(\mathrm{NH}_{4}\right)_{2} \mathrm{SO}_{4}$

The extract was prepared from cells grown as in (B) (see Table 2). Fractions I, II and III were obtained by precipitation with $1.8 \mathrm{M}-, 2.5 \mathrm{M}$ - and $3.8 \mathrm{M}-\left(\mathrm{NH}_{4}\right)_{2} \mathrm{SO}_{4}$ respectively. Activities are mean values from three separate experiments.

\begin{tabular}{|c|c|c|c|c|c|}
\hline \multirow{2}{*}{$\begin{array}{l}\text { Activity } \\
\text { type }\end{array}$} & \multirow{2}{*}{$\begin{array}{c}\text { Assay system } \\
\text { (substrate/coenzyme) }\end{array}$} & \multicolumn{4}{|c|}{$\begin{array}{c}\text { Oxidoreductase activity } \\
{\left[\text { nmol substrate consumed } \min ^{-1}(\mathrm{mg} \text { protein })^{-1}\right]}\end{array}$} \\
\hline & & Crude extract & Fraction I & Fraction II & Fraction III \\
\hline$g d h 1$ & GLD/NADH & 24 & 17 & 79 & 0 \\
\hline$g d h 2$ & DHA/NADH & 54 & 390 & 0 & 0 \\
\hline$g d h 3$ & GLD/NADPH & 21 & 22 & 20 & 65 \\
\hline$g d h 4$ & DHA/NADPH & 97 & 730 & 43 & 18 \\
\hline ADH & Acetaidehyde/NADH & 1650 & 270 & 3700 & 13 \\
\hline
\end{tabular}

The main activity in fraction III was $g d h 3$ together with some $g d h 4$. Chromatography on DEAE-cellulose at $\mathrm{pH} 8.0$ was not possible since neither activity could be adsorbed under these conditions. Using the cation-exchange system carboxymethyl-cellulose (Whatman, CM70), operated at pH 4.5 with $20 \mathrm{~mm}$-acetate, both activities adsorbed but eluted in the same fraction and could not be separated. Gel permeation chromatography on Sephadex G-200 also failed to effect any separation. Through all these attempts at separation the activity ratio $g d h 3: g d h 4$ remained constant at about $3: 1$, suggesting the presence of a single enzyme, glycerol: NADP ${ }^{+}$ oxidoreductase (GDH3).

The results described so far show that $g d h 4$ activity in fraction I is due to GDH2 and that in fraction III to GDH3 but do not yet account for activity in fraction II. Glucose-exponential cells were used for the separation of this activity since GDH2 is repressed under these conditions. Extracts were first brought to $1.6 \mathrm{M}-\left(\mathrm{NH}_{4}\right)_{2} \mathrm{SO}_{4}$ to give a fraction I with negligible $g d h 2$ or $g d h 4$ activity; the $\left(\mathrm{NH}_{4}\right)_{2} \mathrm{SO}_{4}$ concentration was then increased to $2.5 \mathrm{M}$ and the precipitate containing gdh4 activity was further purified by chromatography on DEAE-cellulose. The product contained only gdh4 activity and was thus a glycerol:NADP ${ }^{+}$2-oxidoreductase (GDH4).

\section{Relation between gdh1 activity and $A D H$}

The fourth activity $g d h 1$ and ADH behaved very similarly in all the fractionation procedures. They were both very stable when heated in crude extracts, and after purification through step 2 where they both precipitated mainly in fraction II, they again proved equally heat stable. When fraction II, obtained from glucose-stationary cells, was further purified by chromatography on DEAE-cellulose (step 3), the two activities eluted together. The active fractions were pooled and subjected to gel permeation chromatography on Sephadex G-200 (step 4), but again the two activities could not be separated. The purification was monitored by gel electrophoresis at each step followed by activity staining with $\mathrm{NAD}^{+}$and either ethanol or glycerol as substrate. The final product showed a single protein band which possessed both ADH and gdhl activities.

An alternative purification of ADH was carried out by the rapid method of Scopes (1981), though we were not able to crystallize the enzyme. On electrophoresis this product gave one main protein band and faint, slower running bands, all of which possessed ADH and gdh1 activities. Assays with this product showed that its specific activity when oxidizing GLD was about $3.5 \%$ of its activity with acetaldehyde, while it was inactive with $\mathrm{DHA}$ or with $\mathrm{NADP}^{+}$as coenzyme (Table 4).

\section{DISCUSSION}

We reported initially that $S$. pombe produces an NAD+-linked glycerol dehydrogenase (May $\&$ Sloan, 1981). We have now shown that $S$. pombe produces three more enzymes with glycerol dehydrogenase/triose reductase activity linked to $\mathrm{NAD}^{+}$or $\mathrm{NADP}^{+}$but we have found no evidence for a glycerol oxidase such as has been reported to occur in the fungi Aspergillus, 
Table 4. Substrate specificity of purified $A D H$

ADH was purified and rates of NADH-linked aldehyde (or ketone) reduction or NAD+-linked alcohol oxidation were measured as described in Methods. There was no activity when NADPH replaced $\mathrm{NADH}$ or $\mathrm{NADP}^{+}$replaced $\mathrm{NAD}^{+}$. The values equivalent to $100 \%$ were $130 \mu \mathrm{mol}$ substrate used $\mathrm{min}^{-1}(\mathrm{mg} \text { protein })^{-1}$ for aldehyde reduction and $200 \mu \mathrm{mol}$ substrate used $\mathrm{min}^{-1}(\mathrm{mg} \text { protein })^{-1}$ for alcohol oxidation.

$\begin{array}{lc}\text { Substrate } & \text { Aldehyde reduction } \\ \text { Relative activity }\end{array}$

$\overbrace{\begin{array}{l}\text { Substrate } \\ \text { Ethanol } \\ \text { Glycerol }\end{array}}^{\text {Rlcohol oxidation activity }}$

Table 5. Characteristics of the glycerol dehydrogenases of S. pombe

\begin{tabular}{|c|c|c|c|c|c|c|}
\hline Enzyme & Classification & $\begin{array}{l}\text { Corresponding } \\
\text { EC no. }\end{array}$ & $\begin{array}{l}\text { Cata } \\
\text { activ }\end{array}$ & $\begin{array}{l}\text { ytic } \\
\text { ities }\end{array}$ & $\begin{array}{l}\text { Inducers or } \\
\text { repressors }\end{array}$ & $\begin{array}{l}\text { Role in glycerol } \\
\text { metabolism }\end{array}$ \\
\hline $\begin{array}{l}\mathrm{GDH} 1 \\
(=\mathrm{ADH})\end{array}$ & $\begin{array}{l}\text { Glycerol : NAD } \\
\text { 1-oxidoreductase (a } \\
\text { property of } \\
\text { alcohol : NAD } \\
\text { oxidoreductase) }\end{array}$ & 1.1 .1 .1 & $\begin{array}{l}\text { Acetalde } \\
\text { NADH } \\
g d h 1\end{array}$ & $\begin{array}{l}\text { hyde/ } \\
100 \\
3 \cdot 7\end{array}$ & None & $\begin{array}{l}\text { Uncertain. Could } \\
\text { be significant } \\
\text { since ADH } \\
\text { activity high. }\end{array}$ \\
\hline GDH2* & $\begin{array}{l}\text { Glycerol : NAD }{ }^{+} \\
\text {2-oxidoreductase }\end{array}$ & 1.1 .1 .6 & $\begin{array}{l}g d h 2 \\
g d h 4\end{array}$ & $\begin{array}{r}100 \\
30\end{array}$ & $\begin{array}{l}\text { No induction by } \\
\text { glycerol; strong } \\
\text { repression by } \\
\text { glucose. }\end{array}$ & $\begin{array}{l}\text { Catabolic } \\
\text { utilization of } \\
\text { glycerol as carbon } \\
\text { and energy } \\
\text { source. }\end{array}$ \\
\hline GDH3 & $\begin{array}{l}\text { Glycerol: NADP+ } \\
\text { oxidoreductase }\end{array}$ & $\begin{array}{l}1.1 .1 .72 \\
\text { or } \\
1.1 .1 .21\end{array}$ & $\begin{array}{l}g d h 3 \\
g d h 4\end{array}$ & $\begin{array}{r}100 \\
25\end{array}$ & None & $\begin{array}{l}\text { Uncertain. May } \\
\text { be a specific } \\
\text { glycerol : NADP+ } \\
\text { oxidoreductase or } \\
\text { a broad specificity } \\
\text { aldehyde } \\
\text { reductase. }\end{array}$ \\
\hline GDH4 & $\begin{array}{l}\text { Glycerol : NADP+ } \\
\text { 2-oxidoreductase }\end{array}$ & 1.1 .1 .156 & $g d h 4$ & & $\begin{array}{l}\text { Some induction } \\
\text { by glucose }\end{array}$ & $\begin{array}{l}\text { A specific DHA } \\
\text { reductase } \\
\text { involved in } \\
\text { glycerol synthesis. } \\
\text { Possible role } \\
\text { in xerotolerance. }\end{array}$ \\
\hline
\end{tabular}

* For purification and characterization of GDH2 see Marshall et al. (1985).

Penicillium and Neurospora by Uwajima et al. (1979). The main characteristics of the four enzymes found are summarized in Table 5.

The enzyme we first reported (GDH2) is a glycerol: $\mathrm{NAD}^{+}$2-oxidoreductase (EC 1.1.1.6), the first enzyme in the pathway by which $S$. pombe utilizes glycerol as a carbon and energy source. It is subject to catabolite repression by glucose but not to glycerol induction; though we suggested initially that glycerol may have some inductive effect in strain $972 \mathrm{~h}^{-}$(May \& Sloan, 1981), this is not supported by later work where care was taken to ensure that glucose-stationary cells were only harvested when glucose was no longer detectable in the culture and the cells were fully de-repressed. The purification and characterization of this enzyme is described in the accompanying paper (Marshall et al., 1985). A similar catabolic enzyme has been studied extensively in bacteria such as Klebsiella aerogenes (Aerobacter aerogenes) (McGregor et al., 1974) and Escherichia coli (Tang et al., 1979). 
The enzyme GDH4 is a glycerol:NADP+ 2-oxidoreductase (EC 1.1.1.156). Glycerol appeared to exert no regulatory control on the production of this enzyme, but cells growing exponentially on glucose possessed higher activity than glucose-exhausted or glycerol-growing cells. This stimulation by glucose appeared to be relatively small if activity was measured by the rate of glycerol oxidation but considerably larger if measured by the rate of DHA reduction. This type of enzyme has been found in the fungi Aspergillus niger (Baliga et al., 1962) and Mucor javanicus (Dutler et al., 1977), and in the halophilic alga Dunaliella parva (Ben-Amotz \& Avron, 1974). Its function in Dunaliella appears to be in the synthesis of glycerol, which has been shown to act as an osmoregulatory solute, thus enabling these organisms to tolerate high external solute concentrations (Ben-Amotz \& Avron, 1973). Some xerotolerant yeasts such as Saccharomyces rouxii have also been shown to use glycerol as an osmoregulatory solute (Brown, 1978), when growing in the presence of either high salt concentrations or high sugar concentrations. It seems not unlikely that $S$. pombe, a yeast also able to grow in the presence of $50 \%$ glucose, may possess the same mechanism of xerotolerance, using GDH4 as a synthetic enzyme for glycerol production. If this were so, the apparent inductive effect of glucose on GDH4 may not necessarily be a specific glucose effect but an effect of increased osmotic pressure. Further work is in progress on the characterization of this enzyme, its regulation, and the mechanism of xerotolerance in $S$. pombe.

The properties of the enzyme GDH3 indicate that it is a glycerol:NADP ${ }^{+}$oxidoreductase showing most activity as a GLD reductase but also showing considerable DHA reductase activity. Enzymes with similar properties have been isolated from several sources and they can be divided into two types. The first type, exemplified by the enzymes isolated from the fungus Neurospora crassa (Viswanath-Reddy et al., 1978) and from rabbit muscle (Korman et al., 1972) appears to be relatively specific for glycerol and trioses (EC 1.1.1.72). The second type is a much broader specificity aldehyde or aldose reductase (EC 1.1.1.21), such as has been obtained from the yeasts Candida utilis (Scher \& Horecker, 1966) and a species of Rhodotorula initially isolated by enrichment culture on GLD (Sheys et al., 1971), and from various mammalian tissues such as calf liver (Attwood \& Doughty, 1971) and pig kidney (Bosron \& Prairie, 1972). The limited information we have obtained so far about the properties of GDH3 is not sufficient to decide to which type it belongs or what its metabolic function may be.

The fourth enzyme possessing glycerol dehydrogenase activity was designated GDH1. This activity proved to be inseparable from ADH throughout various attempts at separation, while a purified preparation of ADH from $S$. pombe was found to reduce GLD at about $3.7 \%$ of the rate at which it reduced acetaldehyde, and oxidize glycerol at about $0.3 \%$ of the rate at which it oxidized ethanol (Table 4). This led us to conclude that GDH1 is in fact ADH. In spite of the extensive studies which have been carried out on $\mathrm{ADH}$, particularly the enzymes from horse liver and yeast ('yeast' in this context meaning Saccharomyces), there are few reports of it possessing glycerol dehydrogenase activity. Winer (1958) reported that the horse liver enzyme could reduce GLD at about one-fifteenth the rate for acetaldehyde, while Feraudi \& Schmoltz (1976) considered ADH to be the main enzyme responsible for the reduction of Dglyceraldehyde, L-glyceraldehyde and DHA in rat liver, but neither reported activity in the reverse direction. The yeast enzyme was reported to oxidize glycerol at $0.4 \%$ (Barron \& Levine, 1952) or $0.7 \%$ (van Eys \& Kaplan, 1957) of the rate found for ethanol but neither DHA nor GLD was tested in the reverse reaction. When we tested commercial yeast ADH (Boehringer) for its ability to catalyse oxidation of glycerol or reduction of DHA or GLD, no activity was detected. Thus the ADH from $S$. pombe appears to be more active against glycerol or GLD than the Saccharomyces enzyme. Since $S$. pombe has high ADH activity which does not vary with changes in cultural conditions, a property previously noted by Schlanderer \& Dellweg (1974), the low activity with glycerol or GLD may still make a significant contribution to the overall cellular metabolism of glycerol. To decide whether it does so requires further investigation.

We thank Mrs J. Sloan for her skilful technical assistance and advice. This work was supported in part by a Monash University Special Research Grant and a Monash University Graduate Scholarship to Y.-C.K. 


\section{REFERENCES}

Attwood, M. A. \& Doughty, C. C. (1974), Purification and properties of calf-liver aldose reductase. Biochimica et biophysica acta 370, 358-368.

Babel, W. \& HofmanN, K. H. (1982). The relation between the assimilation of methanol and glycerol in yeasts. Archives of Microbiology 132, 179-184.

Baliga, B. S., Bhatnagar, G. M. \& Jagannathan, V. (1962). Triphosphopyridine nucleotide-specific glycerol dehydrogenase from Aspergillus niger. Biochimica et biophysica acta 58, 384-385.

Barron, E. S. G. \& Levine, S. (1952). Oxidation of alcohols by yeast alcohol dehydrogenase and by the living cell. The thiol groups of the enzyme. Archives of Biochemistry and Biophysics 41, 175-187.

Ben-AMotz, A. \& Avron, M. (1973). The role of glycerol in the osmotic regulation of the halophilic alga Dunaliella parva. Plant Physiology 51, 875-878.

BEN-AMotz, A. \& Avron, M. (1974). Isolation, characterization and partial purification of a reduced nicotinamide adenine dinucleotide phosphate-dependent dihydroxyacetone reductase from the halophilic alga Dunaliella parva. Plant Physiology 53, 628-631.

Bergmeyer, H. U., Holz, G., Kauder, E. M., Möllering, H. \& Wieland, O. (1961). Kristallisierte Glycerokinase aus Candida mycoderma. Biochemische Zeitschrifi 333, 471-480.

Bosron, W. F. \& Prairie, R. L. (1972). Triphosphopyridine nucleotide-linked aldehyde reductase. I. Purification and properties of the enzyme from pig kidney cortex. Journal of Biological Chemistry 247, 4480-4485.

Brown, A. D. (1978). Compatible solutes and extreme water stress in eukaryotic micro-organisms. $A d$ vances in Microbial Physiology 17, 181-242.

DAvis, B. J. (1964). Disc electrophoresis. II. Method and applications to human serum proteins. Annals of the New York Academy of Sciences 121, 404-427.

Dutler, H., van Der BaAN, J. L., Hochuli, E., Kis, Z., TAYlor, K. E. \& Prelog, V. (1977). Dihydroxyacetone reductase from Mucor javanicus. 1. Isolation and properties. European Journal of Biochemistry 75, 423-432.

VAN Eys, J. \& Kaplan, N. O. (1957). Yeast alcohol dehydrogenase. III. Relation of alcohol structure to activity. Journal of the American Chemical Society 79, 2782-2786.

Feraudi, M. \& Schmolz, G. (1976). Reductive metabolism of D-glyceraldehyde, L-glyceraldehyde and dihydroxyacetone in rat liver. Identification of alcohol dehydrogenase as the main responsible enzyme. International Journal of Biochemistry 7, 461466.

Gancedo, C., Gancedo, J. M. \& Sols, A. (1968). Glycerol metabolism in yeasts: pathways of utilization and production. European Journal of Biochemistry 5, 165-172.

Koch, A. L. \& Putnam, S. L. (1971). Sensitive biuret method for determination of protein in an impure system such as whole bacteria. Analytical Biochemistry 44, 239-245.

Kormann, A. W., Hurst, R. O. \& FlynN, T. G. (1972). Purification and properties of an NADP ${ }^{+}$. dependent glycerol dehydrogenase from rabbit skeletal muscle. Biochimica et biophysica acta $\mathbf{2 5 8}$, 40-55.
LIN, E. C. C. (1976). Glycerol dissimilation and its regulation in bacteria. Annual Review of Microbiology 30, 535-578.

Marshall, J. H., May, J. W. \& Sloan, J. (1985). Purification and properties of glycerol: $\mathrm{NAD}^{+}$ 2-oxidoreductase (glycerol dehydrogenase) from Schizosaccharomyces pombe. Journal of General Microbiology 131, 1581-1588.

MAY, J. W. \& SLOAN, J. (1981). Glycerol utilization by Schizosaccharomyces pombe: dehydrogenation as the initial step. Journal of General Microbiology 123, 183185.

May, J. W., Marshall, J. H. \& Sloan, J. (1982). Glycerol utilization by Schizosaccharomyces pombe: phosphorylation of dihydroxyacetone by a specific kinase as the second step. Journal of General Microbiology 128, 1763-1766.

McGregor, W. G., Phillips, J. \& Suelter, C. H. (1974). Purification and kinetic characterization of a monovalent cation-activated glycerol dehydrogenase from Aerobacter aerogenes. Journal of Biological Chemistry 249, 3132-3139.

Mitchison, J. M. (1970). Physiological and cytological methods for Schizosaccharomyces pombe. Methods in Cell Physiology 4, 131-165.

Ruch, F. E., Lengeler, J. \& Lin, E. C. C. (1974). Regulation of glycerol catabolism in Klebsiella aerogenes. Journal of Bacteriology 119, 50-56.

SCHER, B. M. \& Horecker, B. L. (1966). Pentose metabolism in Candida. III. Triphosphopyridine nucleotide-specific polyol dehydrogenase of Candida utilis. Archives of Biochemistry and Biophysics 116, 117-128.

Schlanderer, G. \& Dellweg, H. (1974). Cyclic AMP and catabolite repression in yeasts. European Journal of Biochemistry 49, 305-316.

Scopes, R. K., GRIfFITHS-SMith, K. \& MillaR, D. G. (198I). Rapid purification of yeast alcohol dehydrogenase. Analytical Biochemistry 118, 284-285.

Sheys, G. H., ARnold, W. J., Watson, J. A., Hayashi, J. A. \& Doughty, C. C. (1971). Aldose reductase from Rhodotorula. I. Purification and properties. Journal of Biological Chemistry 246, 38243827 .

Sprague, G. F. \& Cronan, J. E. (1977). Isolation and characterization of Saccharomyces cerevisiae mutants defective in glycerol catabolism. Journal of Bacteriology 129, 1335-1342.

TANG, C. T., Ruch, F. E. \& Lin, E. C. C. (1979). Purification and properties of a nicotinamide adenine dinucleotide-linked dehydrogenase that serves an Escherichia coli mutant for glycerol catabolism. Journal of Bacteriology 140, 182-187.

Thorner, J. W. \& Paulus, H. (1971). Composition and subunit structure of glycerol kinase from Escherichia coli. Journal of Biological Chemistry 246, 3885-3894.

Uwajima, T., Akita, H., Ito, K., Mihara, A., Aisaka, K. \& TeradA, O. (1979). Some characteristics of a new enzyme "glycerol oxidase". Agricultural and Biological Chemistry 43, 2633-2634.

Viswanath-Reddy, M., Pyle, J. E. \& Howe, H. B. (1978). Purification and properties of NADP+. linked glycerol dehydrogenase from Neurospora crassa. Journal of General Microbiology 107, 289-296. 
WADDELL, W. J. (1956). A simple ultraviolet spectrophotometric method for the determination of protein. Journal of Laboratory and Clinical Medicine 48, 311-314.

Winer, A. D. (1958). A note on the substrate specificity of horse liver alcohol dehydrogenase. Acta chemica scandinavica 12, 1695-1696.

WooD, W. I. (1976). Tables for the preparation of ammonium sulfate solutions. Analytical Biochemistry $73,250-257$. 